\title{
Kamu Görevlileri Sendikacılığında İngiltere, Fransa, Almanya ve İsveç Örnekleri
}

\author{
Civil Servants and Trade Unions: British, French, Germany and Swedish \\ Models \\ Hakan CINDEMİ**
}

\begin{abstract}
Özet
Diktatörlükle yönetilen rejimlerde bile çoğunlukla sendikal haklar yer almaktadır. Ancak iktidarın güdümünde olan ve sınırlı alanda hareket edebilen bu sendikalar üyelerinin haklarını korumak ve geliştirmekten ziyade devletin ve siyasal iktidarların hakların korumaya yönelmişlerdir. Bu nedenle bir ülkede demokrasinin ayrılmaz bir parçası olan sendika özgürlüğünün bulunup bulunmadığının belirlemek için ülkede sendikal hakların tanınmış olup olmadığından çok, sendikal hakların hangi kapsamda düzenlendiği ve tanımlandığını tespit etmek gerekmektedir. Uluslararası hukuk düzleminde sendika hakkının, sendikal örgütleme özgürlüğü, toplu sözleşme özgürlüğü ile grev özgürlüğünü de içeren vazgeçilemez bölünemez ve kural olarak herkese tanınması gereken bir insan hakkı olduğu tereddütsüz bir şekilde ortaya konulmuşken ulusal hukuklarda farklı uygulamaların devam ettiği gözlenmektedir. Çalışmada gelişmiş demokrasileriyle bilinen dört ülke Fransa, Almanya, Birleşik Krallık ve İsveç iç mevzuatlarıyla sendikal hakların tanınması ve uygulanması açısından farklı ve önemli örnekler arz ettiğinden ve ülkemizde de sendikal haklara ilişkin tartı̧̧alarda sıklıkla örnek olarak gündeme geldikleri için çalışmamızda inceleme konusu olmuştur.

Anahtar Kelimeler: Kamu Görevlilerinin Sendikal Haklar, Fransa'da Kamu Görevlilerinin Sendikal Hakları, Birleşik Krallık'da Kamu Görevlilerinin Sendikal Hakları, Almanya'da Kamu Görevlilerinin Sendikal Hakları, İsveç Krallığı'nda Kamu Görevlilerinin Sendikal Hakları.
\end{abstract}

\begin{abstract}
Even in regimes governed by dictatorship, trade union rights mostly found. However, these unions, who are guided by government and able to act in limited space, have been protect the rights of the state and political powers, instead of protecting and enhance the rights of their members. For this reason, it is necessary to determine in what extent union rights are regulated and defined, rather than trade union rights are recognized in the country in order to determine whether union freedom an integral part of democracy in a country. It has been unquestionably stated that the right of union on the level of international law is indispensable indivisible, including freedom of association, freedom of association, freedom of collective bargaining and freedom of strike. But it is observed that different practices continue in national laws. The study have been subject of examination The four countries known to have developed democracies, France, Germany, United Kingdom and Sweden because they offer different and important examples of recognition and enforcement of trade union rights through their domestic legislation, and because they are frequent examples of debate on trade union rights in our country.

Key Words: Public Servants Trade Union Rights, Public Servants Syndical Rights in France, Public Servants Syndical Rights in United Kingdom, Public Servants Syndical Rights in Germany, Public Servants Syndical Rights in Sweden.
\end{abstract}

\section{Giriş}

Uluslararası hukuk düzleminde sendika hakkının, sendikal örgütleme özgürlüğü, toplu sözleşme özgürlügü ile grev özgürlüğünü de içeren vazgeçilemez bölünemez ve kural olarak herkese tanınması gereken bir insan hakkı olduğu tereddütsüz bir şekilde ortaya konulmuşken ulusal hukuklarda farklı uygulamaların devam ettiği gözlenmektedir. Bu sebeple Avrupa kıtasındaki ulusal hukuklar açısından belli başlı eğilimleri temsil eden farklı örneklemeleri

\footnotetext{
* Dr., Gaziantep Üniversitesi, Hukuk Fakültesi, hakancindemir@yahoo.com
} 
ülkemizdeki düzenlemelere ve tartışmalara 1şı tutması açısından incelemek önem arz etmektedir.

Çalışmamızda İlk olarak incelediğimiz ulusal hukuklardan Fransa örneği özellikle kamu görevlilerinin statüsü açısından ülkemizle çok paralel olması sebebiyle ele alınmıştır. Zira yirminci yüzyılın ikinci yarısının başlarında Fransız hukukçuları tarafından kamu görevlilerinin statülerinin toplu sözleşme ve grev ile uyuşmadığına ilişkin önemli görüşler ileri sürülmüş ve bu konuda tartışmalar yaşanmıştır. Bu görüş ayrılıklarının neredeyse tamamına yakını günümüzde sona ermiştir. Fransız ulusal hukuku kamu görevlilerinin sendikal haklarına ilişkin düzenlemelerde eksikler olsa da, uluslararası hukuk seviyesine ulaşmış bulunmaktadır. Grev dâhil sendikal hakların kamu görevlilerinin bölünemez, vazgeçilemez bir insan hakkı olduğu küçük bir kesim kamu görevlisi dışında kabul edilmiştir. Kamu görevlileri açısından çok benzer hukuksal alt yapıya sahip olduğumuz Fransa örneğinin bu bağlamda incelenmesi önem arz etmektedir.

Almanya Federal Cumhuriyeti ise, kamu görevlilerinin önemli bir bölümünü oluşturan memurların statülerinin, Fransa'nın tam aksine grev hakkına engel olduğu örnek ülkelerdendir. Ancak Almanya'da da uluslararası denetim organlarının etkisiyle değişim rüzgârları esmeye başlamış mahkemeler mevzuatın değişmesi gerektiğine ilişkin kararlar vermeye başlamışlardır.

Birleşik Krallık ise, özellikle Anglosakson sistemine uygun olarak kamu görevlilerinin yasal statüsünü belirleyecek statüsel bir idare hukuku olmaması açısından kıta Avrupa'sı ve ülkemizden farklı bir örnek teşkil etmektedir.

Son olarak İsveç örneği ise, polis ve asker dâhil bütün kamu görevlilerine toplu sözleşme ve grev özgürlüğü verilmiş olması sebebiyle ulusal hukuklar açısından en ileri örneklerden birisi olarak incelenmiştir. Bununla birlikte devletin kamu görevlilerine lokavt uygulama yetkisi tanıması ülkemizde de mevzuat çalışmaları yapıldığı sırada olumsuz örnek olarak ileri sürülmesine sebebiyet vermiștir.

Söz konusu dört ülke, iç mevzuatları açısından farklılık ve önemli örnekler arz ettiğinden, çalışmamızda inceleme konusu olmuştur.

\section{Fransa Cumhuriyeti’nde Kamu Görevlilerinin Sendikal Hakları}

Türk idare hukukunun Fransız idare hukukundan sadece maddi idare hukuku açısından değil, idari teşkilat ve kamu görevlileri açısından da benzeştiği gözlemlenmektedir. Bu nedenle, Türk statüsel çalışma sisteminin gelişim ve oluşumunda örnek alınan ülke olan Fransa'nın, sistemler arasındaki etkileşim göz önüne alındığında daha derinlemesine incelenmesinde fayda bulunmaktadır.

On sekizinci yüzyıldan itibaren Fransa'da, yardımlaşma dernekleri olarak kurulan ve değişik meslek gurupları arasında yardımlaşmayı öngören birlikler kurulmaya başlanmıştır. $\mathrm{Bu}$ örgütler daha sonra sendikal hakların geliştirilmesinde öncü role bürünmüşlerdir.1

27.02.1948 tarihli Kanun ile Fransa'da kişilerin bir araya gelerek haklarını arama özgürlüğünü tanıyan sendika özgürlüğü yasası kabul edilmiş ancak kanun kabul edildikten bir kaç ay sonra 27.11.1948 de yeni bir kanun ile sendika özgürlüğ̈ kaldırılmış ve sendika kurmak suç olarak düzenlemiștir. Çeșitli mücadeleler sonucunda 25.05.1964 tarihinde çıkarılan kanun ile Ceza Kanununda suç sayılan sendika hürriyeti, suç olmaktan çıkarılmıştır. 21.03.1984 tarihli kanun ile de sendikaların hukukiliği açık olarak tanınmıştır. Söz konusu kanun yürürlüğe girdiğinde Fransa'da zaten hali hazırda 500 civarında sendika bulunmaktaydı. Bu yasayla

1Mesut Gülmez, "Sendika Hakkı ve Kamu Görevlileri," Insan Haklarl ve Kamu Görevlileri (Sempozyum ve Açıkoturum, Bildiriler ve Tartışmalar), (1992): 59. 
birlikte sendikalara serbest kuruluş ilkesi tanınmış, devlet karşısında bağımsızlıkları sağlanmış, işçilerin sendikaya girme ve çıkma hürriyetleri tanınmıştır.2

Kamu görevlileri ise, herkesin sendika kurma hakkına sahip olduğu 1946 Anayasası ile ve yine aynı tarihte çıkarılan memur statüsüne ilişkin kanunla sendika hakkına sahip olmuşlardır.3 1946 yılında memur statüsüne ilişkin kanunla getirilen söz konusu hak özellikle toplu sözleşme ve grev hakkı bağlamında yukarıda değinmiş olduğumuz memur statüsüne ve bu statünün getirdiği güvencelere dair Türk doktrininde de kaynaklık eden tartışmaları doğurmuştur.

Türk hukukuna paralel bir tanımla Fransa'da kamu görevlisi, "kamu tüzel kişilerinden herhangi birisinde, kamu statüsüne tabi olarak maaş karşılığı çalışan kişiler" 4 olarak tanımlanmıştır. Yine benzer bir şekilde, kamu tüzel kişisi tarafından istihdam edilen herkes kamu görevlisi olarak sayılmamış, kamu tüzel kişilerinde çalışanların kamu görevlisi sayılabilmesi için kamu hukukuna tabi olması gerektiği kabul edilmiştir.5 Fransız Uyuşmazlık Mahkemesi 1996 yılında verdiği Berkani kararında, aşçı yardımcısı ile idare arasında yapılan sözleşmenin kamu hukukuna tabi bir sözleşme olduğu kabul edilmiş ve "yaptığ 1 iş ne olursa olsun idareye belli bir statü ilişkisi içinde bağlı olmayan kişilerinde, idare tarafından yerine getirilen idari nitelikli bir kamu hizmetinin görülmesinde çalışıyorsa, kamu hukukuna tabi sözleşme ile idareye bağlandığını" kabul etmiştir.6

Fransız idari personel rejiminde, Türk idari personel rejimiyle paralel olarak bir kamu tüzel kişisi tarafından istihdam edilen herkes kamu görevlisi olmayıp, kamu sektöründe özel hukuka tabi sözleşme ile çalıştırılanlarda mevcuttur. Fransız hukukuna göre bu kişiler kamu hukukuna tabi olmadıkları için kamu personeli sayılmazlar ve bunlarla ilgili çıkabilecek sözleşmesel uyuşmazlıklar adli yargıda karar bağlanır. Yine Fransa'da kamu görevlileri belli bir statüye sahip memurlar ve diğer kamu görevlileri olmak üzere ikili bir ayırımda incelenmektedir.7

Hali hazırda yürürlükte olan, 04.10.1958 tarihli Fransız Anayasasında 1946 Anayasasından farklı olarak başlangıç kısmında veyahut madde metninde grev hakkına değinilmemiş ve Anayasanın 34. maddesinde sendikal haklara ilişkin ilkelerin, çalışma ve sosyal güvenlik hakkıyla birlikte yasalar tarafından belirleneceği hükmü yer almıştır. Bu hükme uygun olarak Fransız Çalışma Kanununda sendikal haklar, grev özgürlüğüyle birlikte düzenlenmiştir. Söz konusu Çalışma Kanununda "kamu görevlileri için yapılan özel düzenlemeler" ismiyle bir başlık açılarak kamu görevlileri diğer çalışanlardan ayrı olarak Türk Hukukuna göre iş kanununa denk düşen Çalışma Kanununda düzenlenmiştir. 8 Ayrıca 13.07.1983 tarihli n83-634 nolu" Memurların Hakları ve Yükümlülüklerini Belirten Kanun" ile de kamu görevlilerini oluşturan memurlar hakkında sendikal haklar düzenlenmiştir.9

\footnotetext{
2 Nizamettin Aktay, Avrupa Birliği Ülkeleri Toplu İş Hukuku, (Ankara: Türk Tarih Kurumu,1997), 84-85.

3 Fransa Anayasası başlangıç kısmında ki düzenlemeye göre, "her kişi, haklarını ve menfaatlerini sendika faaliyetiyle savunabilir ve dilediği sendikaya katılabilir. Grev hakkı, onu düzenleyen kanunlar çerçevesi içinde kullanılır." Anayasanın Türkçeye çevirilmiş tam metni için Bkz. Bülent Nuri Esen, "Fransa Cumhuriyeti Anayasası", Ankara Üniversitesi Hukuk Fakültesi Dergisi 5/1-4 (1948): 1-17.

4 Rene Chapus, "Droit Administratif Général”, Montchrestien 2/15 (2001): 7.

5 Chapus, 25.

6 Tribunal Des Conflits, Berkani, App No:3000, Lebon 25.03.1996, L'actualite Juridiqué Droit Administratif (AJDA), (Paris: Dalloz 1996), 355.

7 Chapus, 228.

8 Kamu görevlilerine ilişkin söz konusu özel düzenlemeler, Fransız Çalışma Kanunun L2512-1 ila L2512-5 maddeleri arasında düzenlenmiştir.

9 Memurların Sendikal Haklarına ilişkin düzenlemeler söz Konusu Kanun 8. ila 10. maddeleri arasında düzenlenmiştir.
} 
Görülmektedir ki Fransız Hukukunda Türk Hukukundan farklı olarak tek ve ayrı bir kamu görevlilerinin sendikal haklarına ilişkin kanun yoktur. Kamu görevlilerinin sendika hakkı iş (çalışma) kanununda ayrı bir bölüm içerisinde düzenlenmiştir. Bir diğer kamu görevlisi gurubunu oluşturan memurlara da, kendi statülerinin düzenlendiği yukarıda belirttiğimiz memurlara ilişskin kanunda sendikal haklarına ilişkin düzenlemeler yapılmıştır.

1983 tarihli "Memur Haklarını ve Yükümlülüklerini" düzenleyen Kanun 8. maddesinde bütün memurların sendikal haklara sahip olduğunu belirtmiştir. Yine Çalışma Kanununun L2512-1 ila 5. maddeleri arasında kamu kurumları, organizasyonları, özel kurum ve organizasyonlardan sorumlu kamu personelinin sendika hakkına sahip olduğu düzenlenmiştir.

Fransa'da sendikaların kuruluşu bir şekil şartına bağlanmamakla beraber, sendikanın kurulup tüzel kişilik kazabilmesi için sendikanın kuruluşunda görev alacak kişilerin isimlerinin yer aldığı kuruluş belgesinin yetkili idari kuruluşa verilmesi gerekmektedir.10 Memurların Hakları ve Yükümlülüklerine ilişkin Kanun'un 8. maddesi uyarınca, Sendikaların asli görevleri üyelerinin haklarını bireysel ve kolektif düzeyde korumaktır. Yine kamu görevlileri sendikaları ulusal bazda olmalıdır. Ayrıca "Kamu alanında çalışanların sendika Hakları ile ilgili düzenlenen 28.05.1982 tarihli 82-447 nolu kararname" uyarınca kamu görevlileri sendikaları federasyon veya konfederasyon olarak örgütlenebilecektir.11 Söz konusu sendikalar genel olarak iş koluna göre kurulmuşsa da mesleki bazda kurulmaları açısından da bir engel bulunmamaktadır.12

Ayrıca bütün çalışanların sendikalara serbestçe üye olabilme hakkı ve üye olmama veya üyelikten çıkma hakkı da teminat altına alınmıştır. Polislerinde sendikaya üye olabilme özgürlüğü düzenlenmiş olmakla birlikte, 28.09.1948 tarihli 48-1504 numaralı polis personelinin özelliklerini belirleyen kanun ile grev polislere yasaklanmıştır.13 Bununla birlikte söz konusu grev yasağı polislerin diğer örgütlenme ve toplantı gösteri yürüyüşü haklarını etkilemez. Örneğin polislerin sivil kıyafetleri ile silahsız olarak, çalışma koşullarıyla ilgili bir konuyu protesto etmek için yürüyüş yapma taleplerini reddeden valilik kararı yargı kararıyla iptal edilmiştir.14

Askeri personel ise grev hakkından yoksun olduğu gibi sendika hakkından da yoksundur. Fransız Savunma Kanunu 1.4121-4 hükmüne göre askerlerin sendikaya üye olmaları yasaklanmıştır. Bu husus doktrinde eleştirilmiş ve katı emir komuta zincirinin sendikal hakların yasaklanması için geçerli bir neden olmadığı savunulmuştur. 15 Avrupa İnsan Hakları Mahkemesi 2014 yılında verdiği iki kararında Fransa'yı askeri personele uyguladığı sendika yasağından dolayı mahkûm etmiş ve ILO denetim organlarına paralel bir kararla asker kişilerin sendikal haklarına sınırlandırmalar getirilebileceği, bununla birlikte sendika hakkının tamamen yasaklanmasının kişi temel hak ve özgürlüklerinin ihlali olacağına karar vermiştir.16 Bu gelişme üzerine Fransız hükümeti tarafından Asker kişiler için daha az kapsamlı olan "light syndicat"

\footnotetext{
10 Alpay Hekimler, Karşılaştırmalı bir Perspektif ile Avrupa Birliği Üyesi Ülkelerde ve Türkiye'de Toplu Sözleşme Sistemleri Mevzuat ve Uygulamalar, (Ankara: Legal Yayınc1lık, 2013), 175.

11 Kamu alanında çalışanların sendika Hakları ile ilgili düzenlenen 28.05.1982 tarihli 82-447 nolu kararname madde no:2.

12 Giuseppe Casale ve Joseph Tenkorang, Public Service Labour Relations: A Comparative Overview, (Geneva, ILO, 2008), s.18.

13 28.09.1948 tarihli 48-1504 numaralı polis personelinin özelliklerini belirleyen kanun madde 2.

14 Didem Fatma Sevgili Gençay, "Fransa'da Kamu Personel Rejimi", Inönü Üniversitesi Hukuk Fakültesi Dergisi 5/1(2014): 237.

${ }_{15}$ Christian Léon, La Liberté Syndicale Des Personnels Militaires: Une Réalité Politique Difficile à Cacher, Actualité Juridique Fonctions Publiques(AJFP) (2005): 249.

${ }_{16}$ EU Court of Human Rights, Case Matelly v. France başvuru no:10609/10 Tarih:02.10.2014 EU Court of Human Rights, Case Adefdromil v. France başvuru no:32191/09Tarih:02.10.2014.
} 
hafif sendika kavramı ortaya atılarak bu yönde asker kişilere de diğer kamu görevlilerine nazaran daha az hak içeren sendika çalışması başlatılacağı duyurulmuştur.17

İllerde üst düzey personel dâhil üst düzey yöneticilerin sendika hakkı bulunmamaktadır bu durum daha önceden de değindiğimiz üzere ILO sözleşmelerine uygundur.18

Fransız Hukukunda sendikalara idareyle ortak kurulan komisyonlar aracılığıyla yönetime katılma hakkı verilmiştir.19 Her bakanlık veya kamu kurumunda sendika konusunda ayrı bir bölüm kurularak, sendikal haklardan yararlanmak isteyen kamu görevlilerinin temsilcilerinin de bulunduğu idare ve memurların eşit bir şekilde temsil edildiği komisyonların oluşturulması gerekmektedir.20 Kamu görevlilerinin statüleri ya da sözleşmeleri ile ilgili olarak yapılacak değişikliklerin önce bu komisyonda görüşülmesi gerekmektedir.21 Kamu görevlileri sendikaları ile idare arasında bu komisyonlar aracılığıyla çalışanların haklarına ilişkin kararlar alınabileceği gibi ayrıca sendikalar ve idare arasında toplu sözleşme akdedilmesi de mümkündür.22

Fransız Hukukunda sendikalarla idare arasında müzakere edilebilecek konular son derece geniş tutulmuştur. Buna göre; çalışma organizasyonları ve tele çalışma organizasyonları, çalışma kariyer planları ve terfiler, mesleki eğitim ve devamlı mesleki eğitim, sosyal çalışmalar ek sivil savunma işlemleri, çalışma alanında kullanılacak olan mesleki sağlık ve güvenlik, temizlik kuralları, engelli personelin işe alınması konusundaki çalışmalar, kadın veya erkekler arasındaki mesleki eşitlik, müzakereye konu olabilecek başlıklardandır.

Sendikalar ve idare arasında toplu sözleşme akdedilmesi de mümkündür. Özel sektörün aksine toplu pazarlık büyük ölçüde merkezileşmiştir. Başbakan kamu hizmetinde işveren tarafını temsil eder. Maliye bakanlığı da, toplu iş sözleşmesi müzakereleri esnasında tüm mali konularda yetkilendirilmiştir.23 Toplu görüşmeler sonrası anlaşmaya varılamaması durumunda hükümetin tek taraflı olarak ücret belirleme yetkisi bulunmaktadır.24 Gönüllü müzakereler sonunda bir anlaşmaya varılması durumunda yapılacak toplu sözleșmelerin hukuki bağlayıcılık kazanabilmesi için hükümet tarafından kanun tüzük ya da yönetmelik gibi düzenlemelere tabi tutulması gerekmektedir. Tek başına söz konusu toplu sözleşmelerin bağlayıcılığı bulunmamaktadır. $25 \mathrm{Bu}$ sebeple özellikle ücretlerin belirlenmesinde toplu pazarlık bütçe kanunundan önce yapılmaktadır.26 Gönüllü uzlaştırma ve tahkim prosedürü de mevcuttur.27

Fransa'da kural olarak bütün kamu görevlilerine grev hakkı tanınmıştır.28 Bununla birlikte bazı özellikli olanların kendi kanunlarında sırf bu meslek guruplarına ilişkin olarak özel

\footnotetext{
17 “Un Syndicat Light Pour Les Militaires”,son güncelleme 25 Aralık, 2016, http://www.liberation.fr.

18Emin Şenver, "AB Üyesi Ülkelerde Kamu Çalışanlarının Örgütlenme ve Grev Hakkı", Kamuda Sosyal Politika, 3/11, (2009): 25.

${ }_{19}$ Chapus, 10.

20 Kamu Alanında çalışanların sendika hakları ile ilgili düzenlenen 28 Mayıs 1982 tarihli 82-447 sayılı kararname, 27 Mart 2015 tarihli değiştirilmiş ek yayım.

Stephen Bach vd., Public Service Employment Relations in Europe: Transformation, Modernization or Inertia?, (London\&Newyork: Routledge 1999), 169.

22 Bach vd. 169.

23 Casale ve Tenkorang, 18.

24Bach vd., 169.

${ }_{25}$ Casale ve Tenkorang, 18.

26 Ali Ekrem Akartürk, 1995 Anayasa Değişikliği Işı̆̆ında Memurların Sendikal Hakları, ( İstanbul: Alkım Yayınevi, 1998), 2-3.

27 Şenver, 25.

281946 Anayasasından farklı olarak 1958 Anayasasında grev hakkı doğrudan düzenlenmemiş sendikal haklara ilişkin düzenlemelerin tamamı olduğu üzere kanuna bırakılmıştır. 13 Temmuz 1983 tarihli memurların hakları ve yükümlülüklerini belirten yasası 10. Maddesi ile memurlara ve Çalışma kanunu L2512-2 madde ise bütün kamu çalışanlarına grev hakkı vermiştir.
} 
bir grev yasağı getirilmiştir. Örneğin polis memurları açısından 28 Eylül 1948 tarihli 48-1504 nolu yasanın ikinci maddesi ile grev yasağı getirilmiştir. Ayrıca ordu mensupları, ceza evi çalışanları, hâkimler, bazı iç işleri bakanlığı iletişim personeline grev yasağ 1 getirilmiştir.29 Bazı kamu çalışanları açısından ise grev süresince de asgari çalışma zorunluluğu getirilmiştir. Örneğin Hastanelerde grev sırasında sağlık hizmetinin tehlikeye düşürülmemesi gerekir. 30 Hastane müdürü grevin sağlık hizmetini tehlikeye düşürüp düşürmediğini kendisi tespit etmek durumundadır.31 Radyo televizyon, hava trafiği kontrolörleri, şehirlerarası demir yolu personeli de asgari hizmet hükümlülügünü sağlamakla yükümlüdür.32

Grev hakkının kullanılabilmesi için kamu görevlisinin ulusal olarak faaliyet gösteren bir sendikaya üye olması gerekmektedir. Dolayısıyla çalışanların bireysel olarak çalışmaktan kaçınması grev kapsamında ele alınamayacaktır. Grev en az 5 gün önceden yetkili makamlara haber verilmelidir. Bildirimde grev nedeni, yeri, saat ve tarihi ile öngörülen grev süresinin belirtilmesi gerekir.33

Fransa mevzuatında Lokavt bir hak olarak düzenlenmemiş olup kamu görevlileri açısından lokavt yasağı bulunmaktadır.34 Bu sebeple Türkiye ile paralel olarak, Fransa'da da memurlar statü hukukuna tabi olarak iş güvencesine sahiptirler. Dolayısıyla grev hakk1 memurların statü hukukundan kaynaklanan güvence ve haklarını zarar vermemektedir.

\section{Birleşik Krallık ’ta Kamu Görevlilerinin Sendikal Hakları}

Diğer ülkelere nazaran Birleşik Krallık'ta daha eski ve derin tarihsel köklere sahip olan bir sendikacılık hareketi söz konusudur. Kendine özgü bir endüstrileşme sürecine sahip olan İngiltere'de, sanayi devriminin gerçekleşmesiyle ortaya çıkan sosyal yapı son derece bozuk ve çarpık bir yapıdır. Fabrika ve atölyelerde çalışan insanların yaşadığı sefalet onları yeni arayışlara itmiştir.35 Sendikacılık "Trade Unionlar" şeklinde ilk defa İngiltere'de bu şekilde ortaya çıkmıştır. Henüz 18. Yüzyılın başlarında bir araya gelen meslek loncaları haklarını aramaya başlamıştır.36

Yeni yeni başlayan söz konusu işçi hareketlerinin önünü kesmek amacıyla 1718 yılında işçilerin bir araya gelerek kurdukları toplulukları yasaklayan ilk kanunda bu hareketlerin akabinde çıkarılmıştır.37 1793 yılında kabul edilen "Yardımlaşma Dernekleri Yasası" günümüz modern işçi sendikalarının öncüsü olan yapıların ortaya çıkmasını sağlamıştır.38

Napolyon savaşları sırasında yürürlüğe giren 1799 tarihli "Örgütlenme Kanunu" işçilerin hem örgütlenme özgürlügünü hem de iş bırakmalarını yasaklamıştır. İngiltere'de sendikalara 1871 tarihinde çıkarılan sendikalar kanunu "Trade Union Act" ile sendikal örgütlenme hakk1 ve toplu sözleşme hakkı tanınmış ancak grev hakkı tanınmamıştır.39 Kamu görevlileri açısından ise, I.Dünya savaşı öncesinde memur birlikleri işçi örgütleriyle birleşmiş

\footnotetext{
29 Sevgili Gençay, 237; Şenver, 25.

30 "Conseil d'Etat (Devlet Konseyi) 7.01.1976 tarihli 92162 sayılı kararında, eğer grev hakkı olan hastane çalışanları grev sırasında, görevlerini ifa edemez durumda olursa, bu kişilerin grev hakkını durdurmak zorundadır yönünde karar almıştır.” Son Güncelleme 19 Kasım.2016 http://www.infosdroits.fr.

31 Bach vd.,74.

32 Sevgili Gençay, 237.

33 Çalışma Kanunu,Madde: L2512-2.

34 Bach vd., 176.

35 Maksut Mumcuoğlu, Sendikacılık, Siyasal İktidar İlişkileri, (Ankara: Doruk Yayınevi, 1979), 34.

36 Akartürk, 4-5.

37 Turhan Esener, İs Hukuku, (Ankara, A.Ü.H.F. Yayınları, 1978), 276-277.

38 Wergin Niels Eric ve White Geoff, "Britanya'da Toplu Sözleşme Sistemi”, Karşılaştırmalı Bir Perspektif ile Avrupa Birliği Üyesi Ülkelerde ve Türkiye’de Toplu Sözleşme Sistemleri Mevzuat ve Uygulamaları, Çev. Gezgin Elif (İstanbul: Legal Yayınevi, 2013) 105.

39 Wergin ve White, 105.
} 
bu nedenle işçilerin sendikal hareketlerine memurlarında katılımı söz konusu olmuștur. Bunun üzerine memur örgütlerinin diğer örgütlere katılımı yasaklanmıştır. 1946 da çıkarılan kanun ile memurlara işçi sendikalarıyla birleşmemek koşuluyla sendika hakkı tanımıştır.40

İngiltere'de kamuda çalışan personel bakımından Kıta Avrupa'sı hukuk sisteminin aksine memur ya da diğer kamu çalışanları için net bir ayrım söz konusu değildir. Anglosakson sistemine uygun olarak kamu görevlilerinin yasal statüsünü belirleyecek idare hukuku gibi bir alan gelişmemiştir.41 Bu sebeple Birleşik Krallık'ta kanunlarla ya da yasama organınca benzer düzenlemelerle belirlenmiş bir memur statüsü bulunmamaktadır. 42 Bununla birlikte gelenekselleşmiş uygulama ve mahkeme kararlarına göre bazı memur tanımlamaları yapılmış yine bu uygulama ve mahkeme kararları uyarınca memurlara diğer kamu görevlilerinden farklı bir statü tanınmıştır.43 Örneğin Avam Kamarası'nın 2003'te yayımladığg Kamu Yönetimi Kanun tasarında memur; "politik ya da adli organlar dışında çalışan, kamu gücünü kullanan, maaşları parlamento tarafından onaylanan, kamu ödeneklerinden alan, kraliyete bağlı ve kadroya sahip görevliler "şeklinde tanımlanmıştır. $44 \mathrm{Bu}$ tanıma göre memurlar kraliçenin emrinde çalışanlardır. Bu kapsamda yerel yönetimlerde çalışanlar, özerk örgütlerde çalışanlar, hâkimler, adli makam personeli memur kategorisinde değildir ancak bunlara ayrı bir personel rejimi de öngörülmüştür.45

Memur dışında bulunan diğer kamu görevlileri ise çoğunlukla bakanlık dışı kamu kurumlarında çalışanlardır. Bununla birlikte memurların yasama tarafından tam olarak düzenlenmiş bir statüsü olmadığı için memur ve kamu görevlisi ayrımı Kıta Avrupa'sı hukuk sisteminde olduğu gibi çok net ve belirgin değildir.

Kural olarak memurlar dâhil kamu görevlilerine sendika hakkı tanınmakla birlikte 1996 tarihli Polis Kanunu ile sendika hakkı polislere yasaklanmıştır.46 Polislere aynı düzenlemeyle grevde yasaklanmıştır. Söz konusu yasakların temeli 1919 tarihli polis grevlerine dayanmaktadır. Askerler için 2011 tarihli silahlı kuvvetler kanununda herhangi bir yasak mevcut değilse de 1975 tarihli "Ordu İçin Kraliçe Nizamnamesi"yle47 ve "1999 tarihli "Kraliyet Hava Kuvvetleri için Kraliçe Nizamnamesiyle" 48 askeri hizmet personelinin sendika hakk1 kabul edilmiştir. Silahlı kuvvet mensuplarına, sendika hakkı verilmekle birlikte toplu sözleşme

\footnotetext{
40 Akartürk, 5 anlamına da uygun olarak, "civil servant" kavramı memur olarak ele alınmıştır.

42 Koray Karası, "Ingiltere" Kamu Yönetimi Ülke Incelemeleri, (Ankara: Ankara Üniversitesi S.B.F.

K.A.Y.A.U.M. Yayınları, 2004), 91. Değerlendirme ve Disipline İlişkin Düzenlemeler", Sayıştay Dergisi, 78, (2010): 131-132.

45 Karasu, 127.

461996 Police Act, c.16, part.3, sec. 64/1

471975 The Queen's Regulations For The Army, J5.588.

481999 The Queen's Regulations for The Royal Air Force, c.13, Part 910, sec.7/f.
}

41 İngilizce dilinden Türkçe'ye çeviri yapan sözlüklerde, "Civil Servant" kelimesinin karşılığı olarak "memur" tanımlaması verilmekteyse de aslında kıta Avrupa'sı hukuk sistemine uygun olan memur kavramı tam çevirisi sivil hizmetkârlar olan "civil servant" kavramına eş değer değildir. Zira Anglo Sakson Hukuk sistemini benimsemiş olan Britanya'da, Kıta Avrupa'sından farklı olarak kamu tüzel kişilerince genel idare esaslarına göre yürütülen asli ve sürekli nitelik taşıyan kamu hizmetlerini yerine getirmekle görevlendirilmiş kişilerin tamamına memur "civil servant" denilmemektedir. Sadece monarşiye ya da günlük dilde kullanılan ifadeyle Kraliçeye, bağlı personele "civil servant" denilmektedir. Merkezi idareye örneğin merkezi idarenin taşra teşkilatına bağlı olarak görev yapan, hatta mahkeme kararları ve uygulamalarla belirli bir statüye kavuşturulmuş, genel idare esaslarına görev yürütülen asli ve sürekli nitelik taşıyan kamu hizmetlerini yerine getirmekle görevlendirilmiş bir kısım kamu görevlisi kraliyete bağlı olmadığı için genelde "civil servant" memur olarak anılmamaktadır. Bununa birlikte bu sınırlar başlı başına kamu görevlerini düzenleyen bir idari mevzuat olmadığı için çok net ve belirgin değildir. Aslında bu durum ilk defa monarşiyle yönetilen devletlerde ortaya çıkan ve saray çevresinde toplanmış, devletin temel işlerini yerine getiren personel şeklindeki memur için yapılan klasik tanıma uygundur. Bu sebeple çalışmamızda sözlük

43 Neil Hawke, Introduction to Administrative Law, (Sydney-London: Cavendish Publishing Limited, 1998$), 248$. 44 Hülya Ekşi Uğuz, "İngiliz Kamu Personel Yönetimine Genel Bir Bakış: Kamu Hizmetlerine Giriş, Performans 
hakkı ve grev hakkı tanınmadığı için çok az asker sendika üyesi olmuștur. Zira söz konusu düzenlemelere göre hizmet personeli dâhil bütün askeri personelin grev yapmaları yasaklanmıştır. Ceza evi personelinin de grev yapması yasaklanmıştır.49

Sendikalar bir kuruluş formu vermek suretiyle kendilerini idare tarafindan tutulan sendikalar listesine ekletebilirler. Bununla birlikte söz konusu sicile kayıt sendikanın kuruluş şartı değildir.50 Hukuk sisteminin özelliği gereği sendikaların faaliyet göstermesi için bir tüzel kişiliğe ihtiyacı yoktur. Dolayısıyla sicile kayıtlı olmayan sendikalarda varlığını sürdürmektedir. Sicil Memurluğu tarafından tutulan söz konusu listeye dâhil olan sendikalar bazı avantajlardan yararlanma hakkına sahip kılınmıştır.51

Kamu görevlileri diğer çalışanlar gibi olumlu ve olumsuz sendika özgürlüğüne sahip kılınmıştır.52 Toplu pazarlık hakkının nasıl kullanacağını detaylı olarak doğrudan düzenleyen bir mevzuat bulunmamaktadır. Bu sebeple İngiliz Hukukunda toplu pazarlık yöntemi açısından gönüllü müzakere yöntemi kabul edilmiştir. İşyeri düzeyinde veya mesleki düzeyde toplu pazarlık mümkündür.

Toplu pazarlık "National Whitley" konseyi ve Karma İstişare Komitesi vasıtasıyla gerçekleştirilir. Söz konusu kurullarda memur sendikaları ile devlet eşit sayıda temsil edilir.53 $\mathrm{Bu}$ kurulların verdiği kararlar hükümet tarafından aynen uygulanır. Anlaşma sağlanamayan durumlarda gönüllü tahkim öngörülmüştür. Ücretler, çalışma saatleri, y1llık izinler, emeklilik ve çalışma koşulları toplu sözleşmenin kapsamında olup toplu sözleşmede yer alabilir. Toplu sözleşme sadece sendikaya üye olan kamu görevlilerine uygulanacak olup üye olmayanların kapsama alınmasını sağlayacak hukuki bir müessese düzenlenmemiştir.54

Kural olarak memurlar dâhil bütün kamu görevlilerinin grev hakkı mevcuttur. Bununla birlikte değindiğimiz üzere polis, ceza evi personeli ve askerlerin grev hakkı bulunmamaktadır.

\section{Almanya Federal Cumhuriyeti'nde Kamu Görevlilerinin Sendikal Hakları}

Sanayileşmiş ülkelerdeki birçok benzeri gibi Almanya Federal Cumhuriyeti'nde de çalışma hayatına ilk dönemlerde lonca düzeni hakim bulunmaktaydı. 19. yüzyılın ortalarında meslek guruplarının kendilerine yardımı için doğan sendikalar uzun müddet kendilerine yönelik kolektif özgürlüklerin yasaklanmasının kaldırılmasına çalıştılar. Fransız devriminin etkisiyle 1869 yılında sendikal örgütlenme üzerindeki yasaklar önemli ölçüde kaldırılmıştır. 1878 tarihinde Sosyalizm Kanunu ile birlikte tekrar iş mücadelesi araçlarını kullanma özgürlüğü yasaklanmıştır. 1890 yılında Sosyalizm Kanunu yürürlükten kaldırılmış, 1919 Weimar Anayasasının 159. ve 165. maddeleriyle sendika hürriyeti Anayasal garanti altına alınmış ancak bu güvencenin iş mücadelesi araçlarını kapsayıp kapsamadığı tartışma konusu olmuştur.55

1933 yılından itibaren Nasyonal Sosyalistler iktidara gelmiş ikinci dünya savaşının bitimi olan 1945 yılına kadar iktidarda kaldıkları süre içerisinde kolektif iş hukuku müesseseleri tamamıla etkisiz hale getirmiștir.56 Hala yürürlükte olan 1949 Alman Anayasası her mesleğe ekonomik çıkarlarını ve çalışma koşullarını korumak geliştirmek için örgütlenme hakkı tanımıştır. Bu hüküm, 1953 yılında kamu görevlilerini de içine alacak şekilde genişletilmiştir.

\footnotetext{
491994 Criminal Justice and Public Order Act, sec.127.

501992 Trade Union and Labour Relations Act, Part I, c.I.

51 Pitt, s.320-321.

521992 Trade Union and Labour Relations, 1993 Trade Union Reform and Employment Rights.

53 Taşkent Savaş, "Memurların Toplu Pazarlık Hakkı", Cumhuriyet, 28 Ocak (1994): 5.

54 Casale ve Tenkorang, 30-31.

55 Aktay, 3-4.

56 Aysen Tokol, Türk Endüstri İlişkileri Sistemi, (Bursa: Dora Yayınları, 2012), 6.
} 
Almanya Federal Cumhuriyeti'nde kamu görevlileri, memurlar (beamte), yardımc1 hizmetlerde sözleşmeli çalışanlar ve işçiler olmak üzere üç temel guruba ayrılmıştırlar. Memurların statüleri, görevleri, bağlı bulundukları idari kurumları, kamu hukukuna tabi olarak istihdam edilirken, sözleşmeli çalışanlar ile işçiler özel hukuka dayanan sözleşme ile istihdam edilmektedir. Memurlar kamunun asli görevlerini yerine getirirken sözleşmeli personel ve işçiler kamu gücünün uygulanması açısından geçici nitelikte görevlere sahiptirler. Anayasanın 33. maddesi gereği memurların maaş, emeklilik ve diğer haklarının federal yasalarla düzenlenmesi gerekmektedir.57

Almanya Federal Cumhuriyeti'nde memurlar için anayasal güvenceler getirilmiştir. Anayasanın 33. maddesiyle vatandaşlık ile memurluk arasında bir bağ oluşturmuştur. Buna göre kamu hizmetlerinin düzenli bir şekilde yürütülmesi memurlara emanet edilmekte ve memurların "kamu gücünü" temsil ettikleri ve devletle özel bir çalıșma ilișkisi içinde oldukları öngörülmektedir.58 Memurlarında kamu hizmetlerini düzenleyen kurallarla belirlenmiş olan memurluğun gelenek ve adetlerine uygun davranması gerekmektedir.59 Alman idari personel sisteminde, memurlar anayasal sistemi koruyan sadık kişiler olarak tanımlanmış olup bu sebeple anayasaya aykırı üyeliklerden uzak durması gerektiği düzenlenmiştir.60

Almanya Federal Cumhuriyeti Anayasasının örgütlenme özgülüğüyle ilgili olan 9. maddesinin birinci fikrasına göre her vatandaş dernek kurma hakkına sahiptir. Üçüncü fikraya göre de çalışma ve ekonomik koşulları korumak ve geliştirmek için, sendika kurma hakkı herkes ve bütün meslekler için güvence altına alınmıştır. Yine üçüncü fikra gereği sendikal faaliyetler doğal afetler, kamu düzeni veya güvenliği, federasyonu tehdit eden savaş hallerinde dahi kisitlanamaz ve engellenemez.

Olumlu ve olumsuz sendika özgürlüklerinin herkes için kabul edildiği Almanya'da böylelikle çalışan herkesin sendikalara üye olma hakkı mevcuttur. 61 Dolayısıyla cezaevi personeliyle birlikte, askerler ve polislerde sendika hakkından yararlanabilirler.

9 Nisan 1949 tarihli Toplu Sözleşme Kanunu ile işçilerin toplu pazarlık ve toplu sözleşme hakkı güvence altına alınmıştır. Aynı kanun kamu görevlileri olan yardımcı hizmetlerde sözleşmeli çalışanlar ve işçiler içinde toplu pazarlık ve toplu sözleşme hakkı tanımıştır. Bununla birlikte memurların toplu sözleşme hakkı bulunmamaktadır.62 Yine benzer bir şekilde kamu görevlileri olan yardımcı hizmetlerde sözleşmeli çalışanlar ve işçiler dâhil bütün çalışanların grev hakkı mevcutken prensip itibariyle memurların grev hakk1 bulunmamaktadır. 63

Daha önceden de değindiğimiz üzere memurların sendikal haklara sahip olmasına rağmen grev ve toplu pazarlık hakkına sahip olmamasının nedeni, statü hukukuna tabi memurların kanunlarla belirlenmiş statülerinin değiştirilmesini talep edemeyeceği görüşüdür. Memurların grev yasağı ile ilgili açık bir kanun maddesi ya da anayasa hükmü bulunmamaktadır. Söz konusu yasak eski tarihli bir Almanya Federal Cumhuriyeti Anayasa

\footnotetext{
57 Selim Çapar, "Almanya'da Kamu Personeli Sistemi", Türk İdare Dergisi, 466 (2010), 51.

58 Taşkent, 5.

59 Onur Ender Aslan, Kamu Personeli Rejimi, (Ankara: T.O.D.A.İ.E., 2005), 181

60 Nigel Foster ve Satish Sule, German Legal System and Laws, (Newyork: Oxford University Press, 2010), 218.

61 Volker Rieble, “Almanya Federal Cumhuriyeti'nde Toplu Sözleşme Sistemi”, Karşılaştırmalı bir Perspektif ile Avrupa Birliği Üyesi Ülkelerde ve Türkiye'de Toplu Sözleşme Sistemleri Mevzuat Uygulamaları, (İstanbul, Legal Yayinevi, 2013) 32.

62 Casale ve Tenkorang, s.21.

63 David Westfall ve Gregor Thüsing, "Strikes and Lockouts in Germany and Under Federal Legislation in the United States: A Comparative Analysis", Boston College International and Comprative Law Review, 22, (1999):32.
} 
Mahkemesi kararına dayanmaktadır.64 Mahkeme Anayasanın 33. maddesi gereği memurların grev yapamayacağına karar vermiştir.

Alman Anayasası madde 33/3'e göre egemenlik hak ve yetkilerinin yerine getirilmesi daimi olarak sadakat ilişkisinde bulunan kamu görevlilerine bırakılmıştır. Madde $33 / 5$ 'e göre de kamu hizmetleri hukuku, memurluğun gelenek ve adetlerini göz önüne alarak düzenlenir. Anayasa mahkemesi söz konusu kararında $33 / 5$ e dayalı olarak memurluk gelenek ve adetlerinde grevin olmadığına değinerek memurların grev yapamayacağına karar vermiştir.

Söz konusu görüş zayıflayarak da olsa Alman idare hukukunda günümüzde de yerini korumaktadır. Bu görüşe göre memurlar devlete sadakat ilişkisiyle bağlı olarak zaruri ve önemli görevleri yerine getirmektedir, bunun gereği olarak kamu görevlerinin aksatılmaması gerekir.65

Ayrıca bir diğer görüşe göre memurların çalışma koşulları kanunlarla düzenlenmektedir, kanunlar karşısında iş mücadelesi araçlarına başvurulması mümkün değildir. 66 Ancak bu görüşün etkisini zamanla yitirmeye başlamıştır. Zira temel ihtiyaç maddeleri ve hizmetlerini üreten işletmelerde çalışmamak ve kamu gücünü kullananlar arasında olmamak şartıyla istisnai nitelikteki memurlara grev hakkı tanınmıştır.67 Dolayısıyla kanunla statüleri belirlenmişte olsa istisnai bu memurlar çalışma koşullarını ve ücretlerinin düzeltilmesi için grev yapabilmektedirler.

Daha öncede belirttiğimiz üzere ILO denetim organlarının yanı sıra, Avrupa İnsan Hakları Mahkemesi kararlarında da Almanya Federal Cumhuriyeti'nin memurlara uyguladığı grev yasağı eleştirilmiş ve Almanya'nın Avrupa İnsan Hakları Sözleşmesinin 11. maddesini ihlal ettiğine karar verilmiştir. Bu doğrultuda Almanya Federal İdare Mahkemesi 2014 yılında verdiği bir kararında memur olan öğretmenlerin grev yapamayacaklarına hükmetmiştir. Ancak kararının gerekçesinde, Almanya Federal Cumhuriyeti Anayasasının genel olarak memurlara grev hakkını yasakladığını belirtmekle birlikte, bu durumun Avrupa İnsan Hakları Sözleşmesinin 11. madde ile ters düştüğünü tespit etmiş ve sözleşme ile Federal Anayasa arasındaki bu çelişkinin kanun koyucular tarafından giderilmesi gerektiğini belirtmiştir.68

\section{İsveç Krallığı’nda Kamu Görevlilerinin Sendikal Hakları}

İsveç'te de sendikacılık köklü ve uzun bir geçmişe dayanır. "Stockholm Matbaacılar Sendikası" ilk sendika olarak 1846 yılında kurulmuştur. 1870'li yıllardan itibaren sendikal örgütlenme ülke çapında yaygınlaşmış ve meslek esasına göre sendikalar kurulmaya başlamıştır.69

Kamu görevlilerinin sendikal haklarını elde etmeleri uzun mücadeleler sonunda olmuştur. İlk önce dernek olarak kurulan kamu görevlileri birlikleri, daha sonra toplu sözleşmesiz ve grevsiz sendikal örgütlenme özgürlügüne sahip olmuştur. 1936 senesinde İsveç Parlamentosu özel sektörde çalışanlara sendikal örgütlenme hakkını tanımıştır.70 Nihayetinde

\footnotetext{
64 Federal Anayasa Mahkemesi, BVerfG, 11.06.1958 - 1 BvR 1/52; 1BvR 46/52 karar1.

${ }_{65}$ E. Ursula Koch E., Angriffaufein Monopol: Gewerkschaften Ausserhalbdes DGB, (Köln: Deutscher İnstitus Verlag, 1981), 119.

66 Rieble, 34-35.

67 A. Can Tuncay, "Kamu Görevlilerinin Sendikalaşması ve Toplu Pazarlık Hakkı", Dokuz Eylül Üniversitesi Hukuk Fakültesi Dergisi, 9 (2007)157.

68Almanya Federal İdare Mahkemesi, 27.02.2014-2C1/13 nolu kararı.

69 Murat Demircioğlu, "İsveç Sendika Hareketi Üzerine Notlar", Cahit Talas'a Armă̆an, (Ankara: Mülkiyeliler Birliği Yayını, 1990) 193.

70 Ahmet Erol, Demokrasi Örgütlenme Özgürlüğü ve İsveç Örneği, (Ankara: Kültür Bakanlı̆̆1 Yayınları, 1995), 123.
} 
1966 yılında polis ve ordu mensupları dâhil bütün kamu görevlilerine örgütlenme, toplu pazarlık ve grev hakkı tanınmıştır.71

Genel olarak İsveç'te kamu görevlileri ve özel sektör çalışanlarına aynı kurallar uygulanır. Bu kapsamda özel sektör çalışanlarına uygulanan 1974, 1976 ve 1978 çalışma kanunları kamu görevlilerine de uygulanmaktadır. Memurlarda dâhil, kamu çalışanlarının özlük hakları ve statülerini tamamıla düzenleyen ayrı bir idare hukuku mevzuatı bulunmamaktadır. Bununla birlikte kamu görevlilerinin düzenlenmiş hiç bir statülerinin olmadığını savunmak hatalı olacaktır. Zira 1994 Kamu Görevi Kanunu ve 1994 Kamu Çalışanları Kanunu kamu görevlilerine ilişkin birçok düzenleme getirmiştir. 1994 Kamu Görevlileri Kanunu, kamuda çalışan personelin haklarını ve yükümlülüklerini düzenlerken, 1994 Kamu Çalışanları Kanunu da söz konusu personelin disiplin kurallarını düzenler. Dolayısıyla kamu personeli açısından çok önemli olan, çalışanların hakları, yükümlülükleri ve disiplin soruşturmaları özel sektör çalışanlarından farklı olarak düzenlenmiştir. Bu sebeple kamu çalışanlarına sadece bu iki düzenlemenin dışında kalan hususlarda özel sektör çalışanlarının tabi olduğu kurallar uygulanacaktır. Kanunlarla yapılan düzenlemelerin dışında kamu görevlilerinin çalışma koşulları sektörel olarak toplu sözleşmelerle belirlenmektedir.72

Hükümet kamu çalışanlarının büyük bir çoğunluğunu özerk kuruluş makamı olan ajanslara bağlamıştır. Toplam 250 ajansa sektörel olarak bağlanan kamu görevlerinin işe alınması, yönetimi ve işten çıkarılması bu ajanslar tarafından yapılmaktadır. Söz konusu ajanslar hükümet tarafından altı yıllık süre için atanan yöneticiler tarafindan idare edilir. Ajansların işleyiş biçimlerine hükümetin müdahale yetkisi bulunmamaktadır. Dış işleri personeli, Polis ve Askeri personel ise hükümete bağlı olup herhangi bir ajansa bağlanmamıştır. Söz konusu 250 ajansın üye olduğu İsveç Kamu Çalışanları Ajansı "Arbetsgivarverket" 73 (SAGE) kamu çalışanlarının sendikaları ile toplu pazarlık konusunda tek yetkili olup, kamu görevlilerinin sendikalarıyla yapılacak toplu sözleşmeleri imzalama yetkisine sahiptir. 1994 senesinde kurulan SAGE, 250 Ajansın yöneticilerinden oluşmaktadır. 74 Toplu sözleşmenin yapılmasıyla ilgili olarak devletin hiç bir müdahale hakkı bulunmamaktadır.75 Bütün yetki İsveç Kamu Çalışanları ajansınındır.76

Üst düzey yöneticiler dâhil, kamu görevlilerinin tamamı sendika hakkına sahiptir.77 Bununla birlikte küçük bir azınlık gurup hariç, kamu görevlilerinin üst düzey yöneticilerini de içeren bir şekilde statülerine dayalı çalışma güvenceleri bulunmamaktadır. Özel sektör çalışanları gibi, Ajanslar tarafından bir bölümün yeniden yapılandırılması ya da kapatılması gibi nedenlerle işten çıkarılabilirler. Diplomatlar, Polis ve Askerler devlet tarafindan atanmış olup bu kapsam dışındadır ve kamu görevlisi statüsüne dayalı iş güvencesine sahiptirler. Ayrıca Ajans yöneticileri de, altı yıllık süreler için bakanlar kurulunca atandıklarından görevleri altı

\footnotetext{
71 Olle Söderman, Türkiye'de Kamu Çalışanlarının Sendikal Haklarl ve İsveç Örneği Sempozyumu,(İstanbul: Pan Yayıncılık, 1988), 54; Taşkent, 5.

72 Ministry of the Presidency, Public Employment In European Union Member States, (Madrid: Ministry of the Presidency Technical Secretariat, 2010), 238.

73 Kurumla ilgili detaylı bilgi için bkz. "Arbetsgivarverket”, Son güncelleme 05 Ocak, 2017. http://www.Arbetsgivarverket.se.

74 Ministry of the Presidency, 239.

75 Sture Björnguist, İsveçte Basın ve Yayın, İsveçte Örgütlenme Özgürlüğü ve Sendikal Haklar, (Ankara: Yorum Basın Yayın, 1990), 90

76 Ajansların devlet politikaları açısından değerlendirilmesi ve İsveç devletiyle olan ilişkisi için bakınız, Jon Pierre, "Politicization of Swedish Civil Service: A Necessary Evilor Just Evil?", Politicization of The Civil Service in Comparative Perspective: The Quest Of Control, (London\&Newyork, Routledge, 2004), 48-55.

77 J. Lindholm, "Demokratik Toplumların Oluşması, Sendikaların, Demokratik Örgütlerin Özgürce Çalışmasına Bağlıdır”, Türkiye'de Memur Sendikacılı̆ğ Uluslararası Sempozyumu-13-14 Eylül 1990, (Ankara: Mülkiyeliler Birliği Vakfı Yayınları, 1990), 45.
} 
yıllık süre sonunda kendiliğinden sona erecektir ve SAGE dâhil Ajanslar tarafından görevden alınamayacaklardır.78 İsveç'te sendikaların kuruluşu ve faaliyetleri ile ilgili özel düzenlemeler yapılmamıştır. Bu sebeple sendika kurabilmek için özel şartlar aranmamaktadır.79

Hali hazırda yürürlükte olan 1975 tarihli İsveç Anayasası on yedinci maddesine göre bütün sendikalar Grev yapabilirler. Bu kapsamda sendika üyesi olan kamu görevlilerinin de, sendika aracılığı ile toplu sözleşme yapma ve grev hakkı bulunmaktadır.80 Polis ve Asker dahil bütün kamu görevlilerinin grev hakkı bulunmaktadır.81 Bunun tek istisnası devleti temsil eden yüksek düzeydeki memurlardır. Bu memurların sendika hakkı olmakla birlikte grev hakkı bulunmamaktadir. 82

Kamu görevlilerinin neredeyse tamamının grev hakkına sahip olmasına karşın devlet de lokavta başvurabilme yetkisine sahiptir. Bu nedenle grev sırasında kamu görevlilerinin maaşları ödenmeyebilir. Ancak sendikaların lokavt süresinde üyelerinin ödenmeyen maaşlarını, kendisinin ödeme yetkisi mevcuttur. 83

İsveç, doktrinde çoğu zaman çalışanların sendikal hakları ile örgütlenmeleri açısından en ileri seviyede düzenlenip, tanındığ 1 ülke olarak kabul edilmiştir. 84 Kamu görevlilerinin grev hakkına ilişkin olarak da, sendikal hakların bütün çalışanlara tam kapsamıyla verilmiş olması sebebiyle örnek gösterilen İsveç'in, kamu personeli uygulamaları, ülkemizde siyasi düzlemde eleştiriye uğramıştır.85 Söz konusu görüşler, özellikle İsveç'te grev yapan kamu görevlilerine karşı devletin lokavt yapabilmesi ve memurların özelleştirildiği ileri sürülmüş, bu durumun kamu görevlilerinin aleyhine olduğu savunulmuştur.

Söz konusu görüşe katılmak mümkün değildir. Zira her şeyden önce İsveç'te kamu görevlileri özelleştirilmemiştir. Devlet tarafından kurulan özerk kuruluşlara bağlanmıştır. Yine kamu görevlilerinin özerk kuruluşlara bağlanması kamu görevlilerinin sendikal haklarını tam kapsamıla elde etmesinden uzun süre sonra meydana gelmiştir. Dolayısıyla söz konusu özerkleştirme sendikal haklara koşut bir düzenleme değildir. Ayrıca, Polis, dış işleri personeli ve askeri personel hali hazırda doğrudan devlete bağlıdır ve grev hakları mevcuttur. Dolayısıyla doğrudan devlete bağlı klasik anlamda memurlarında İsveç'te grev hakkı bulunmaktadır. Kamu görevlilerinin bir kısmının özerk kuruluşlar oluşturarak devredilmesi, tamamen o ülkenin ekonomik yapılanması, personel rejimi anlayışı ve kamu hizmetine bakış açısıyla ilgilidir.

78 Ministry of the Presidency, 240. Pierre, 49

79 Reinhold Fahlbeck, "Collective Labour Law in Sweden", Banksis 1. Uluslararası semineri: "Kara Avrupa'sl ve Türkiye'de Kollektif İş Hukuku ve Uygulaması", Çev. Can Tuncay, (İstanbul: Cihad Matbaası, 1985), 223-226.

80 Şenver, 26.

81 Akartürk, 4.

82 Erol, 124.

83 Peter Scherer, "Diğer Kapitalist Demokrasilerde Kamu Kesimi Grevleri", Sosyal Siyaset Konferansları Dergisi, 28, (1977): 119.

84 Akartürk, 4; Erol, 48-51; Nusret Ekin, Endüstri İlişkileri, (İstanbul: İstanbul Üniversitesi Yayınları, 1979), 9394.

85 Anayasa Komisyonu Sözcüsü Coşkun Kırca TBBM genel kurulunda özetle; "lokavt hakkı olmayacak mı? İsveç'te memurun grev hakkı var; ama, devletin lokavt hakkı da var. Hem memura grev hakkı isteyeceğiz hem de devlete lokavt hakkını tanımayacağız ve böylece, memuru, sendikalı işçiden bile daha imtiyazlı bir hale getireceğiz, Lokavt hakkı olmadan, grev hakkı... Memurlar, İskandinav ülkelerinde böyle yapıyor demek kolay. Onlar ne yapmışlar; memurluğu özelleştirmişler. Bizim anladığımız anlamda çok az memur kalmış. İş akdiyle çalışıyorlar... bizim tespitlerimize göre, dünyada, memur sendikasına, toplu iş sözleşmesi hakkı tanımış memleket yoktur. Memurunuzu, işçi yapmışsanız, özelleştirmişseniz Danimarka ve İsveç gibi, o ayrı; ama, biz, bunu yapamayız. Bu, bizim geleneklerimize de, ihtiyaçlarımıza da aykırı."demiştir. Konuşmasının tam metni için bkz. TBMM Genel Kurul Tutanağı, 19. Dönem 4. Yasama Y1l1 123. Birleşim 14.06.1995 Çarşamba, TBMM Tutanak Dergisi, (1995) 392 
Sendika hakkının mütemmim cüzü olan grev hakkı ise insan hakları ve demokrasi anlayışıyla ilgilidir. İki husus bir biriyle tamamen farklıdır ve karıştırılmamalıdır.

Kamu görevlilerinin grev yapması durumunda devlete kanun koyucu tarafindan tanınmış lokavt yetkisi de yine o ülkenin endüstriyel bakış açısıyla ilgilidir, lokavt grev hakkının olmazsa olmaz karşılığ yada mütemmim cüzü değildir. Bununla birlikte grev sırasında çalışanların ücretlerinin ödenmemesi durumu, çalışana hiç bir grev hakkı tanınmamasından her halükarda daha demokratik ve çalışan lehine bir durumdur. Zira çalışan açısından, grev süresince hiç ücret alınamaması, bütün çalışma hayatı boyunca kötü çalışma şartları ve düşük ücret sarmalında bırakılması durumundan son derece daha lehe olacaktır. Ayrıca İsveç örneğinde de olduğu gibi çalışanlar, örgütleri aracılığıyla bu ekonomik zorluğu aşmanın bir yöntemini bulacaktır. Dolayısıyla sendikal haklar açısından son derece ileri düzenlemelere sahip İsveç örneğine ilişkin yukarıda belirttiğimiz eleştirel siyasi görüşler kamu personelinin korkutularak bu hakkının peşine düşmesini engellemeye yönelik eleştirilerden öteye geçmemektedir.

\section{Sonuc}

Özellikle Avrupa açısından bakıldığında AİHM kararlarının iç hukuka etkisiyle birlikte Uluslararası anlaşmalara uygun bir şekilde kamu görevlilerinin sendikal hakları açısından özgürlükçü bir yaklaşım ortaya konulmaya başlanmıştır. Bu kapsamda sendikalı olabilecek meslek guruplarının önündeki engeller ve sendikalı olamayacak meslek gurupları her geçen gün azalmaktadir.

Sendikal hakların tam olarak kullanılması açısından sadece sendikal örgütlenme hakkı değil ayrıca toplu sözleşme ve grev hakkı da kamu görevlilerinin önemli bir çoğunluğuna sağlanmıştır. Grev hakkının kamu görevlilerine tanınmasının önünde set oluşturan statülü personelin grev hakkına sahip olamayacağı görüşü terk edilmiştir. Bu görüşün yerine katılımcı demokrasi için devlet yönetiminde etkin olan kamu personelinin, çalışma koşullarında söz sahibi olmasının daha demokratik bir toplum için gereklilik olduğu görüşü yerleşmiştir. Alman mahkemeleri tarafindan dahi bu görüş benimsenmiş olup yasa koyucu bu doğrultuda anayasa yapmaya davet edilmiştir.

Sendikal hakların uluslararası alanda kabul gören, bölünmez bir bütün olarak sendikal örgütlenme hakkı, toplu sözleşme hakkı ve grev hakkını kapsayan temel bir insan hakkı olduğu görüşü Avrupa ülkelerinin iç hukuklarında yer bulmaya başlamıştır.

\section{Kaynakça}

Aktay, Nizamettin, Avrupa Birliği Ülkeleri Toplu İs Hukuku, Ankara: Türk Tarih Kurumu,1997.

Arbetsgivarverket “Arbetsgivarverket”, Son güncelleme 05 Ocak, 2017. http://www.Arbetsgivarverket.se.

Aslan, Onur Ender, Kamu Personeli Rejimi, Ankara: T.O.D.A.İ.E., 2005.

Bach, Stephen, Bordogna Lorenzo, Rocca Giuseppe Della, Winchester David, Public Service Employment Relations in Europe: Transformation, Modernization or Inertia?, London\&Newyork: Routledge 1999.

Björnguist, Sture, İsveçte Basın ve Yayın, İsveçte Örgütlenme Özgürlüğ̈̈ ve Sendikal Haklar, Ankara: Yorum Basin Yayın, 1990.

Casale, Giuseppe ve Tenkorang Joseph, Public Service Labour Relations: A Comparative Overview, Geneva, ILO, 2008.

Chapus, Rene, “Droit Administratif Général”, Montchrestien 2/15 (2001).

Christian Léon, La Liberté Syndicale Des Personnels Militaires: Une Réalité Politique Difficile à Cacher, Actualité Juridique Fonctions Publiques(AJFP) (2005).

“Conseil d'Etat (Devlet Konseyi) 7.01.1976 tarihli 92162 sayılı kararı.” Son Güncelleme 19 Kasım.2016 http://www.infosdroits.fr.

“Conseil d'Etat (Devlet Konseyi) 7.01.1976 tarihli 92162 sayılı kararı.” Son Güncelleme 19 Kasım.2016 http://www.infosdroits.fr.

Çapar, Selim, "Almanya'da Kamu Personeli Sistemi", Türk İdare Dergisi, 466 (2010). 
Demircioğlu, Murat, "İsveç Sendika Hareketi Üzerine Notlar", Cahit Talas'a Armağan, Ankara: Mülkiyeliler Birliği Yayını, 1990.

Ekin, Nusret, Endüstri İlişkileri, İstanbul: İstanbul Üniversitesi Yayınları, 1979.

Ekrem, Akartürk Ali, 1995 Anayasa Değiş̧ikliği Işığında Memurların Sendikal Hakları, İstanbul: Alkım

Yayınevi, 1998.

Erol, Ahmet, Demokrasi Örgütlenme Özgürlüğü ve İsveç Örneği, Ankara: Kültür Bakanlı̆̆ı Yayınları, 1995.

Esen, Bülent Nuri, "Fransa Cumhuriyeti Anayasası", Ankara Üniversitesi Hukuk Fakültesi Dergisi 5/1-4 (1948).

Esener, Turhan, Iss Hukuku, Ankara, A.Ü.H.F. Yayınları, 1978.

Fahlbeck, Reinhold, "Collective Labour Law in Sweden", Banksis 1. Uluslararasl semineri: "Kara Avrupa'sl ve Türkiye'de Kollektif İ̦ Hukuku ve Uygulaması", Çev. Can Tuncay, İstanbul: Cihad Matbaası, 1985.

Foster, Nigel ve Sule Satish, German Legal System and Laws, Newyork: Oxford University Press, 2010.

Gülmez, Mesut, "Sendika Hakkı ve Kamu Görevlileri," Insan Hakları ve Kamu Görevlileri (Sempozyum ve Açıkoturum, Bildiriler ve Tartışmalar), (1992).

Hawke, Neil, Introduction to Administrative Law, Sydney-London: Cavendish Publishing Limited, 1998.

Hekimler, Alpay, Karşılaştırmalı bir Perspektif ile Avrupa Birliği Üyesi Ülkelerde ve Türkiye'de Toplu Sözleşme Sistemleri Mevzuat ve Uygulamalar, Ankara: Legal Yayıncılık, 2013.

Karasu, Koray, "İngiltere" Kaти Yönetimi Ülke İncelemeleri, Ankara: Ankara Üniversitesi S.B.F. K.A.Y.A.U.M. Yayınları, 2004.

Koch E. Ursula, Angriffaufein Monopol: Gewerkschaften Ausserhalbdes DGB, Köln, Deutscher İnstitus Verlag, 1981.

Lindholm J., "Demokratik Toplumların Oluşması, Sendikaların, Demokratik Örgütlerin Özgürce Çalışmasına Bağlıdır", Türkiye'de Memur Sendikacılı̆̆ı Uluslararası Sempozyumu-13-14 Eylül 1990, Ankara: Mülkiyeliler Birliği Vakfı Yayınları, 1990.

Ministry of the Presidency, Public Employment In European Union Member States, Madrid: Ministry of the Presidency Technical Secretariat, 2010.

Mumcuoğlu, Maksut, Sendikacıllk, Siyasal İktidar İlişkileri, Ankara: Doruk Yayınevi, 1979.

Pierre, Jon, "Politicization of Swedish Civil Service: A Necessary Evilor Just Evil?", Politicization of The Civil Service in Comparative Perspective: The Quest Of Control, London\&Newyork, Routledge, 2004.

Rieble, Volker, "Almanya Federal Cumhuriyeti'nde Toplu Sözleşme Sistemi”, Karşılaşstırmalı bir Perspektif ile Avrupa Birliği Üyesi Ülkelerde ve Türkiye'de Toplu Sözleşme Sistemleri Mevzuat Uygulamaları, İstanbul, Legal Yayınevi, 2013.

Scherer, Peter, "Diğer Kapitalist Demokrasilerde Kamu Kesimi Grevleri", Sosyal Siyaset Konferansları Dergisi, 28, (1977).

Sevgili, Gençay, Fatma Didem, "Fransa'da Kamu Personel Rejimi", İnönü Üniversitesi Hukuk Fakültesi Dergisi $5 / 1(2014)$.

Söderman, Olle, Türkiye'de Kamu Çalışanlarının Sendikal Hakları ve İsveç Örneği Sempozyumu, İstanbul: Pan Yayıncilık, 1988.

Şenver, Emin, "AB Üyesi Ülkelerde Kamu Çalışanlarının Örgütlenme ve Grev Hakkı", Kamuda Sosyal Politika, $3 / 11,(2009)$.

Taşkent Savaş, "Memurların Toplu Pazarlık Hakkı", Cumhuriyet, 28 Ocak (1994).

TBMM Genel Kurul Tutanağı, 19. Dönem 4. Yasama Yılı 123. Birleşim 14.06.1995 Çarşamba, TBMM Tutanak Dergisi, (1995).

Tokol, Aysen, Türk Endüstri Ilişskileri Sistemi, Bursa: Dora Yayınları, 2012.

Tribunal, Des Conflits, Berkani, App No:3000, Lebon 25.03.1996, L'actualite Juridiqué Droit Administratif (AJDA), Paris: Dalloz 1996.

Tuncay A.Can, "Kamu Görevlilerinin Sendikalaşması ve Toplu Pazarlık Hakkı", Dokuz Eylül Üniversitesi Hukuk Fakültesi Dergisi, 9 (2007).

Uğuz, Hülya Ekşi, "İngiliz Kamu Personel Yönetimine Genel Bir Bakış: Kamu Hizmetlerine Giriş, Performans Değerlendirme ve Disipline İlişkin Düzenlemeler", Saylştay Dergisi, 78, (2010).

Wergin Niels Eric ve White Geoff, "Britanya'da Toplu Sözleşme Sistemi", Karşılaştırmalı Bir Perspektif ile Avrupa Birliği Üyesi Ülkelerde ve Türkiye'de Toplu Sözleşme Sistemleri Mevzuat ve Uygulamaları, Çev. Gezgin Elif, İstanbul: Legal Yayınevi, 2013.

Westfall David ve Thüsing Gregor, "Strikes and Lockouts in Germany and Under Federal Legislation in the United States: A Comparative Analysis", Boston College International and Comprative Law Review, 22, (1999). 